\title{
Charging the Budget of the City Wroclaw with Urbanisation Costs (Poland)
}

\author{
${ }^{1}$ Maria Hełdak, ${ }^{2}$ Ken Chisa \\ ${ }^{1}$ Wroclaw University of Environmental and Life Sciences, C. K. Norwida 25, Wrocław 50-375, Poland \\ ${ }^{2}$ University of KwaZulu-Naatal, Department of Information Science, Pietermaritzburg South Africa
}

\begin{abstract}
The paper deals with the issue of charging local authorities with the costs of realisation of the provisions contained in local spatial development plans in Wrocław (Poland). Considering the planned spatial development in the area of the city Wrocław, the urbanisation costs that are chargeable to the municipality budget were identified. The economic effects of preparing areas designated for development in the residential programme offer were analysed. The paper provides an analysis of the cost of realisation of investments that belong to own duties of the municipality, including the cost of building municipality roads, sewage and water supply networks, arranging public greenery and purchasing land for public investments. The analyses were performed within the administrative borders of the city. The prognosed costs of the realisation of local spatial development plans demonstrate significant expenditure that Wrocław has to incur for the construction of sewage network and municipal roads. Additionally, the development of new areas will require the city of Wrocław to take over the real properties on which public goals are planned to be realised. One should thoroughly consider the actual need for new investment areas in the city. Demographic forecasts demonstrate that the areas designated for development significantly exceed the demand.
\end{abstract}

Keywords: Financial effects of urbanisation, Costs of realisation of spatial development plans

\section{Introduction}

The local spatial development plan is the only planning document in Poland that is an act of local law. As a result, the provisions concerning the designation of areas and principles of their development are generally binding. It is also the only planning document with such high legal status. When adopting the resolution on preparing the local spatial development plan, the Municipal Council should be aware of the financial consequences of the document as early as at the stage of drawing up the plan. Due to that, the legislatory authority imposed the obligation to prepare a forecast of the financial results of adopting the local spatial development plan. Such forecast shall estimate the revenues and expenditures of the municipality that result from adopting the plan (Cymerman, Bajerowski, Kryszk, 2010). Information contained in the forecast may safeguard municipal authorities against the emergence of unexpectedly high costs resulting from the payment of compensation for damages for the negative impact of the local spatial development plan. The forecast may also identify potential opportunities to obtain revenues from the realisation of the provision of the plan (Cymerman, Bajerowski, Kryszk, 2010). It estimates own revenues as well as the costs incurred by the municipal budget with respect to the realisation of the tasks of the municipality (Hełdak, Płuciennik, 2017). In Chinese urbanization, most cities have a special project management mode called "Agent Construction Model (ACM)" has been adopted to manage and govern these projects under the same umbrella of administrative standards. Massive construction projects are government-funded ( $\mathrm{Li}, \mathrm{Lu}, \mathrm{Kwak}$, Dong, 2015).

Data contained in the forecast may also be helpful in choosing the direction of the investment financing policy and in preparing annual financial plans of the municipality. The provisions of the local spatial development plan constitute the basis for the realisation of investments and obtaining a building permit (Hełdak, Raszka, 2013; Hełdak, Raszka, Szczepański, 2016).

The identification of financial expenditures of the municipality results from the Act on Local Self-Government (Act on Local Self-Government), which provides a list of tasks that should be realised by the self-government authorities of the 
municipality. Pursuant to the Act, own tasks of the municipality consist in satisfying the collective needs of the community, including, among others, the own tasks that are most commonly estimated in the forecast, i.e. the issues of: real property management, municipal roads, streets, bridges and squares and road traffic organisation, issues related to water supply and the relevant networks, sewage, municipal wastewater discharge and treatment, maintain order and sanitary facilities, landfills and municipal waste disposal, local public transport, physical education and tourism, including recreational areas and sports facilities, municipal greenery and trees and municipal cemeteries.

The Report on the economic losses and social costs of uncontrolled urbanisation in Poland (Report..., 2013) states that local spatial development plans in their current form have a faulty functional structure, because the areas designated for residential development are too large and often exceed the needs and economic capacity of the municipalities multiple times. Some local spatial development plans foresee the development of areas, whose demographic absorption capacity exceeds the population of the municipality even ten times. Additionally, a large part of the areas designated for development does not meet the basic requirements for investments, because the municipalities cannot afford to prepare them appropriately.

The main objective of this study is to analyse the economic consequences that may be caused by local spatial development plans for the city of Wrocław that identify areas for residential development in the prepared offer. The research referred to the costs of realisation of the provisions of local spatial development plans that may encumber the budget of Wroclaw municipality in connection with the housing programme.

\section{Research Methodology}

The realisation of the objective of the study required the authors to obtain information with use of the direct observation method. Information about the area discussed in the paper was obtained from the disclosed planning documentation, i.e. local spatial development plans, master maps of the area and maps from the Wrocław Spatial Information System. The costs incurred by the municipality budget were identified basing on the provisions of local spatial development plans. Costs of realisation of local spatial development plans identified in the housing programme were determined considering the division most commonly used in literature, according to the following groups (Hełdak, 2013; Cymerman, Bajerowski, Kryszk, 2008; Hełdak, Płuciennik, 2018):

- financial charges for negative consequences affecting real properties (compensations specified in Art. 36, item 1, point 1 and item 3 of the Spatial Planning and Management Act),

- financial charges connected with purchasing real property for the realisation of public goals,

- financial charges connected with the costs of the construction of infrastructure,

- financial charges connected with handling the investment process.

The analysis of costs incurred by the municipality for the realisation of own tasks connected with acquiring real property for the realisation of public goals required the authors to determine average transaction prices basing on data contained in the Real Property Price and Value Register, obtained from the Land Surveying, Cartography and Municipal Cadastre Office in Wrocław. Information about existing transportation networks and utility networks obtained as a result of the analysis of master map enabled us to identify the necessary investment related to infrastructure. The cost of realisation of planned construction works and infrastructure facilities (the construction of roads, land utility networks, development of green areas and construction of educational facilities) was obtained from price catalogues of construction objects. The research area located in the city of Wrocław is presented on the map (Figure $1 \mathrm{~A}, \mathrm{~B}$ ). 


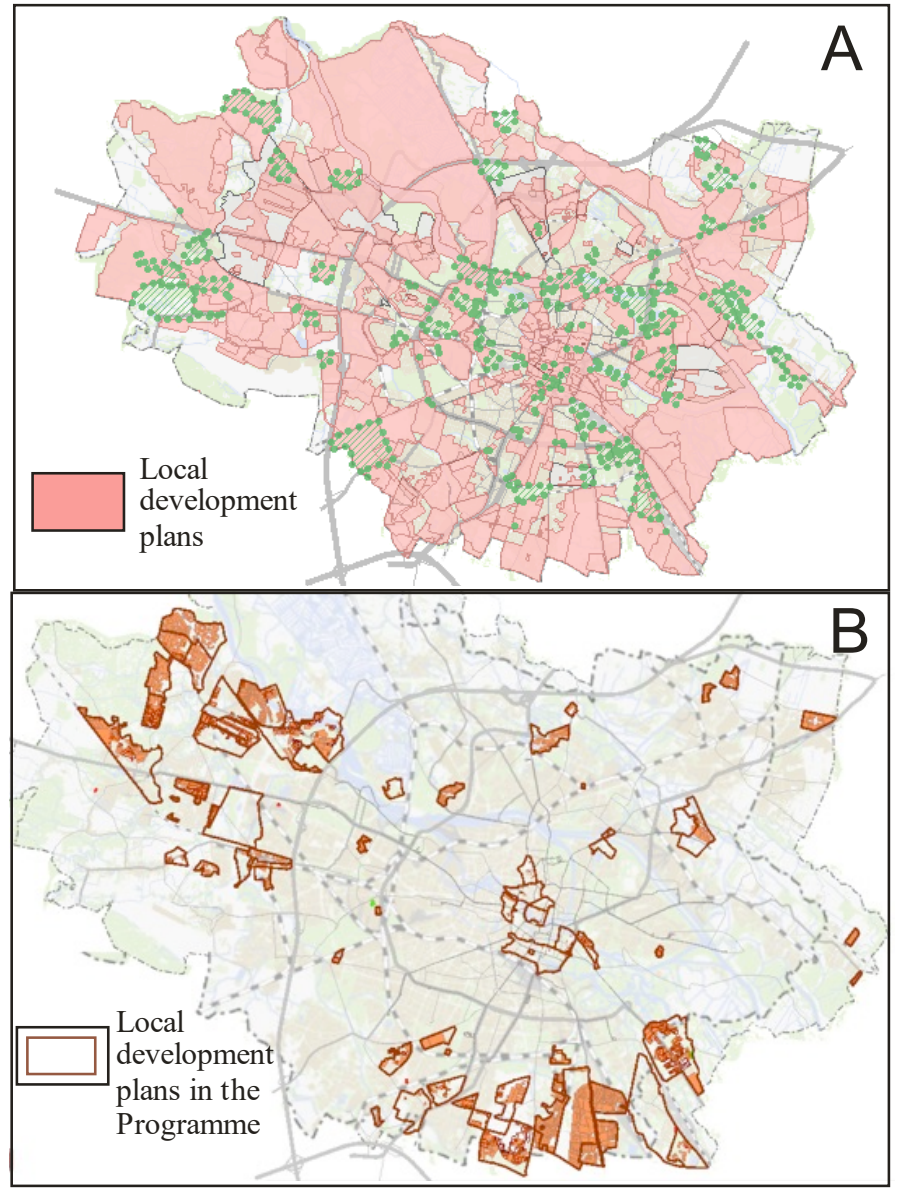

Figure. 1: $A$, B. A - Location the local development plans in Wrocław (Poland). B - Location of the areas subject to analysis in terms of the costs of realisation of the provisions of local spatial development plans (area in the Programme for preparing offers of areas for residential developmen).

The concept design of the sewage and water supply networks prepared as part of the housing programme of the Wrocław municipality constituted the basis for calculating the length of the network that needs to be developed in order to service new investment areas.

\section{Housing Programme of the Wroclaw Municipality}

In response to the urban development needs and the increasing demand for new areas for residential development, the authorities of Wrocław prepared an offer of areas designated for multi-family and single-family housing. The intention of this enterprise was to provide attractive areas for residential development in various parts of the city. The offers included both areas owned by the municipality and those that are in the possession of other entities. Some of the factors that determined the attractiveness of the designated areas, included: the possibility to make them available soon, the differentiation of offers in terms of their type and the nature of planned development, and the fact that specific areas were scattered across the layout of the whole city. The Programme for preparing offers of areas for residential development (2012), foresaw that residential areas for approx. 120000 inhabitants would be made available.

According to the newest demographic forecasts of the Central Statistical Office (GUS), the population of Wrocław will increase by approx. 11 thousand people in the next 13 years (i.e. by approx. 2\%) - the population of the city at the end of 2016 was 637683 people). Wrocław remains one of the few cities, where an increase in population is predicted. At the same time, the housing programme foresees the mobilisation of areas for approx. 120 thousand inhabitants. The programme is not fully adjusted to demographic prognoses.

The main changes in the capital of Lower Silesia concern the oldest age groups and thee working age population. Although the group aged 15-64 will remain the largest, it quickly loses its position to the post-working age population. The disadvantageous changes in demographic structure based on age have already begun: 
- the share of the working age population will decrease while at the same time the share of the immobile group will grow;

- the process of demographic ageing is progressing (the share of the post-working age group will rise to reach nearly $26 \%$ ).

\section{Costs of Construction of the Sanitary Sewage and Water Supply Net- works}

\subsection{Water Supply Network}

The analysis of the local spatial development plans designated for the realisation of the housing programme demonstrated that approx. $42 \mathrm{~km}$ of water supply network should be constructed. The cost of construction of the water supply network was estimated based on the data from the Construction Facilities Price Bulletin BCO "SEKOCENBUD", vol. II, Engineering facilities from the $4^{\text {th }}$ quarter of 2018, volume 70/2018 (1840). Prognosed construction technology: PE-HD pipes $\varnothing 160 \mathrm{~m}$, cast iron valves, underground fire hydrants, disinfection of pipelines, sand substrate under the pipeline, layer thickness $10 \mathrm{~cm}$ (item No. 5566 C. Unit price (per $1 \mathrm{~m}$ ) of the network, considering the regional coefficient (for the Lower Silesian Voivodeship it equals 0,952) is PLN 360 (84 EUR). Thus, the estimated construction cost of the water supply network is approx. PLN 15120000 (EUR 3528 000).

\subsection{Construction of Sanitary Sewage System}

The analysis of the local spatial development plans demonstrated that approx. $42 \mathrm{~km}$ of sanitary sewage network should be constructed. The cost of construction of the water supply network was estimated based on the data from the Construction Facilities Price Bulletin BCO “SEKOCENBUD”. Prognosed construction technology: PVC pipes Ø 250 mm, concrete circular manholes $\varnothing 1200 \mathrm{~mm}$, sand substrate under the sewer, layer thickness $15 \mathrm{~cm}$, sealing test (item No. 5575). Unit price (per $1 \mathrm{~m}$ ) of network, considering the regional coefficient, is PLN 1200 (EUR 280). The total construction cost of the sanitary sewage and water supply networks is approx. PLN 50400000 (EUR 11760 000).

The city has developed a method for co-financing the construction of water supply and sewage networks and road infrastructure. This is due to the fact that the development of housing in Wrocław faces problems resulting from the lack of underground utility structures and road infrastructure.

The co-operation offer refers to these areas of the city that were approved for residential development in the municipal spatial policy.

\section{Financial Charges Connected with Purchasing Real Property for the Realisation of Public Goals}

The municipality is obliged to purchase land designated for public investments. In connection with the realisation of the provisions of the analysed plans, the municipality Wrocław will have to purchase land in locations designated for urban greenery areas, new communication routes of access road class and local class. However, the areas qualified for the housing programme are mostly locations with good communication accessibility, where most of the roads are already owned by the municipality.

The costs of purchasing land designated for access roads in the local spatial development plan were estimated based on the adopted average price per $1 \mathrm{sqm}$, which was obtained from the analysis of the market of real properties being roads or designated for roads. This price amounts to PLN 180 (EUR 42) and urban greenery areas PLN 120 (EUR 28). The surface area required to be purchased was estimated based on the analysis of the provisions of plans in connection with the analysis of the ownership status of the real properties. In order for land to be qualified for purchase, it has to be designated for the realisation of public goals in the local spatial development plan. Internal roads constitute a significant part of the communication areas. The entities responsible for the construction of such roads are the owners of adjacent real properties (co-owners of the road). Such solution reduces the costs on part of the Municipality, but it hinders the construction and maintenance of roads, because of the difficulties in reaching a consensus between co-owners of the adjacent land plots with respect to the construction and maintenance of the road. The surface areas and land purchase costs are listed in Table 1. 
Table 1. List of the prognosed costs of land purchase for the purposes of the realisation of public goals.

\begin{tabular}{|c|c|c|c|}
\hline Item & $\begin{array}{c}\text { Land designation for the realisa- } \\
\text { tion of public goals }\end{array}$ & $\begin{array}{c}\text { Surface area of land desig- } \\
\text { nated for the realisation of } \\
\text { public goals } \\
{[\text { ha] }}\end{array}$ & $\begin{array}{c}\text { Prognosed land purchase } \\
\text { cost } \\
\text { [EUR] }\end{array}$ \\
\hline 1. & $\begin{array}{c}\text { Public communication areas }- \\
\text { commune roads and walk- } \\
\text { ways/transport routes }\end{array}$ & 30,00 & 12600000 \\
\hline 2. & Public park green areas & 25,60 & 7168000 \\
\hline 3. & $\begin{array}{c}\text { Areas of public educational ser- } \\
\text { vices }\end{array}$ & not estimated & not estimated \\
\hline 4. & TOTAL: & $\mathbf{5 5 , 6 0}$ & $\mathbf{1 9 7 6 8 ~ 0 0 0}$ \\
\hline
\end{tabular}

Source: authors' compilation

The analysis revealed that the highest costs are connected with the purchase of land for the purposes of the realisation of public roads. The total amount that the municipality may pay for purchasing land for public roads in the given area is approx. EUR 12600000 .

In Germany, betterment levies are charged, considering the real cost of the construction of infrastructure facilities, while in Poland the basis for the calculation of the fee is the increase in real property value. Pursuant to $\S 128 \mathrm{BauGB}$ in Germany (Ziniewicz, 2012, Hełdak, Płuciennik 2017), the costs of realisation of local infrastructure include:

- $\quad$ the acquisition and preparation of land for the realisation of infrastructure;

- $\quad$ expenditures on the construction of the given investment;

- $\quad$ expenditures on adapting the existing facilities to the local technological infrastructure system (Ziniewicz, 2012).

In England all investors are also charged with infrastructure fees, based on uniformly applied indicators (The Community Infrastructure Levy Communities..., 2008). Apart from those levies, planning obligations and technical infrastructure conditions are binding.

In Poland, the Act on Revitalisation introduced the provisions concerning the possibility to co-finance costs that accompany the development as a result of adopting a local spatial development plan for revitalisation. Currently, investors, including developers, often do not bear any costs of the development of technological infrastructure facilities. Moreover, they never bear the costs of the construction of social infrastructure. The expenses related to the construction of educational, cultural, sports and leisure facilities on local level are borne by the municipality budget.

\section{Costs of Construction of Public Roads}

The cost of construction of municipal local roads, access roads and shared pathways for pedestrian and motor traffic were estimated pursuant to the Uniform Standards of valuation of buildings and structures, Volume 126. The realisation of investment was estimated based on item No. 72 (local roads and squares with mastic asphalt paving) of the following parameters: mechanical trenching, $15 \mathrm{~cm}$ thick sand drainage layer, $18 \mathrm{~cm}$ thick B- 7.5 gravel-concrete substructure, concrete curbs $44,72 \mathrm{~m} / 100 \mathrm{~m}^{2}, 3 \mathrm{~cm}$ thick asphalt-concrete paving. The cost of realisation of $100 \mathrm{~m}^{2}$ of this type of paving, considering the multiplication coefficient for the region (for the Lower Silesian Voivodeship this indicator falls into the range $(0.77-0.88)$, the adopted value was 0.80$)$ is PLN 18831 (4 382 EUR). The paving surface area was calculated based on the measurement of road length from the drawings in the plan (length of roads $-20 \mathrm{~km}$ ) and the assumed roadway width, which was $6 \mathrm{~m}$. It was determined that the surface area that required paving was $120000 \mathrm{~m}^{2}$. The calculated total cost of construction of municipal access roads in the areas covered by the housing programme was approx. EUR 5258400. 


\section{Discussion}

The investment areas specified in the housing offer are only a fraction of all areas designated for development in the local spatial development plans that are binding within the administrative borders of Wrocław. Considering that the areas covered by the housing programme may accommodate approx. 120 thousand new residents, there are definitely too many of them. Currently in Poland, in the course of preparing the local spatial development plan, a forecast of the financial effects is also prepared, and new development areas are designed only provided that there is a demand. The needs are determined in the area balance, based on long-term demographic prognoses and on the current designation status of the areas. Considering the prognosed population of Wrocław in the next 13 years, which is supposed to increase by approx. 11 thousand according to estimations, the demand for new areas is rather low.

Excessive scattering of development results not only in high costs of providing utility infrastructure, but it also generates numerous additional costs connected with the need to ensure access to community services. The research revealed the costs of realisation of the housing programme (Table 2.).

Table 2. List of costs of realisation of the analysed Program for preparing offers of areas for residential development.

\begin{tabular}{|c|c|}
\hline Specification & $\begin{array}{l}\text { Costs } \\
{[\mathbf{E U R}]}\end{array}$ \\
\hline $\begin{array}{l}\text { Buyout of real properties intended for the implementation of public } \\
\text { goals - commune roads and walkways/transport routes }\end{array}$ & 12600000 \\
\hline $\begin{array}{l}\text { Buyout of real properties intended for the implementation of public } \\
\text { goals - Public park green areas }\end{array}$ & 7168000 \\
\hline Construction of municipal roads & 5258400 \\
\hline Construction of paths for pedestrians and cyclists & not estimated \\
\hline Construction of sanitary sewage system & 11760000 \\
\hline Construction of water supply system & 3528000 \\
\hline Construction of a street lighting network & not estimated \\
\hline Financial impact related to setting up public green areas & not estimated \\
\hline TOTAL: & 40314400 \\
\hline
\end{tabular}

Source: authors' compilation

The construction and maintenance of municipal roads also generate high costs, connected, among others, with taking over the public communication area in return for compensation, road construction and providing ongoing maintenance works (repairs of the paving, snow removal) (Hełdak, Stacherzak, Kazak, 2011). As a result, municipalities adopt various design solutions with respect to the roads designed in the local spatial development plan. The most common solution is designing internal roads instead of public roads. The realisation of such roads does not belong to own tasks of the municipality so it will not encumber the municipal budget in the future. On the other hand, new problems arise, as it is difficult for a group of several tens or even hundreds co-owners of the road to reach consensus regarding its construction, and later maintenance and repairs. Although such solutions are also present in the housing programme, some of the roads already have a regulated legal status.

\section{Conclusion}

The conducted analysis allowed the Authors to formulate the following conclusions:

1. The costs of the realisation of the provisions of local spatial development plans included in the Wrocław housing offer are quite significant, although they do not exceed the financial possibilities of the municipality.

2. The main problem of the spatial policy of the city Wrocław is the fact that the surface area of the locations designated for development significantly exceeds the actual demand. The demographic prognosis does not confirm that it is justified to designate such large area (approx. $45 \mathrm{ha}$ ) for development, considering the capacity of these areas that may accommodate approx. 120 thousand inhabitants.

3. Preparing a local spatial development plan gives the municipality a possibility to decide about certain costs related to its realisation. As far as communication is concerned, this usually takes the form of searching for design solutions 
that reduce the costs of realisation of the provisions of the plan. One of the solutions is to designate the necessary communication routes for internal road areas. Such designation releases the municipality from the obligation to build the road, but, at the same time, it hinders the realisation of the communication accessibility goal.

\section{References}

- Baugesetzbuch (BauGB) z 27 sierpnia 1997, BGBI. I S. 2141.

- Central Statistical Office in Poland (GUS). Retrieved 20.03.2019 from http://www.gus.pl/

- Cymerman, R., Bajerowski, T., Kryszk, H. (2008). Prognoza skutków finansowych uchwalenia miejscowego planu zagospodarowania przestrzennego, [The forecast of financial impacts resulting from the adoption of the local spatial development plan] Olsztyn, EDUCATERRA.

- Hełdak, M., Raszka, B. (2013). Evaluation of the local spatial policy in Poland used in the Wrocław poviat with regard to sustainable development. Polish Journal of Environmental Studies, Vol. 22, No. 2 (2013).

- Hełdak, M. (2013). Prognozowanie finansowych skutków uchwalenia planu miejscowego [Forecasting the financial impacts of adopting a local development plan]. Warszawa, Texter.

- Hełdak, M., Raszka, B., Szczepański, J. (2016). Design of Ground Surface Sealing in The Spatial Policy of Communes. World Multidisciplinary Civil Engineering-Architecture-Urban Planning Symposium 2016, WMCAUS Praha 2016, Procedia Engineering, 161 (2016). Crossref

- Hełdak, M., Płuciennik, M., (2017). Costs of Urbanisation in Poland, Based on the Example of Wrocław. IOP Conference Series: Materials Science and Engineering; ISSN 1757-8981 [p]; ISSN 1757-899X [e]; 2017; Vol. 245, 032052. DOI: 10.1088/1757-899X/245/7/072003. Crossref

- Hełdak, M. Płuciennik, M. (2018). Ekonomiczne aspekty decyzji planistycznych na przykładzie miasta Wrocławia [Economic aspects of planning decisions - the case of Wroclaw city]. Prace Naukowe Uniwersytetu Ekonomicznego we Wrocławiu. Gospodarka przestrzenna - stan obecny i wyzwania przyszłości [Research Studies of Wrocław University of Economics. Spatial economy - current status and future challenges]; ISSN 1899-3192 [p]; ISSN 2392-0041 [e]; ISBN 978-83-7695-687-9; Wrocław : Wrocław University of Economics Press, 2018; No. 504. DOI: 10.15611/pn.2018.504.06. Crossref

- Local spatial development plan in the area of western part of Marszowice Malownicze III development area in Wrocław, the Resolution by the City Council of Wrocław dated November 20, 2003 (Official Journal of Lower Silesia Voivodship dated April 20, 2004, No. 71, item 1337).

- Local spatial development plan in the area of Kominiarska, Jubilerska and Sułowska Streets as well as the Wrocław motorway ring road in Wrocław, the Resolution by the City Council of Wrocław No. LXI/1566/14 dated October 7 , 2014 (Official Journal of Lower Silesia Voivodship from 2014, item 3223).

- Li ,Y. Lu, Y. Kwak, Y.H. Dong, S. Developing a city-level multi-project management information system for Chinese urbanization, International Journal of Project Management, Volume 33, Issue 3, April 2015, https://doi.org/10.1016/j.ijproman.2014.06.011Crossref

- Newsletter of Prices in the Construction Industry "SEKOCENBUD” (2018), 70/2018 (1840). Ośrodek Wdrożeń Ekonomiczno - Organizacyjnych Budownictwa "PROMOCJA” Sp. z o. o.,

- Raport o ekonomicznych stratach i społecznych kosztach niekontrolowanej urbanizacji w Polsce. Instytut Geografii i Przestrzennego Zagospodarowania. Fundacja Rozwoju Demokracji Lokalnej [The report on economic losses and social costs of uncontrolled urbanization in Poland. Institute of Geography and Spatial Organization. Foundation for the Development of Local Democracy], Warsaw, 2013.

- Regulation of the Minister of Transport and Maritime Economy of March 2, 1999, on technical conditions to be met by public roads and their location (Official Journal from 1999 No. 43, item 430).

- The Act dated March 8, 1990, on Municipal Self-Government (consolidated text Official Journal from 2018, item 994, as amended).

- The Programme for preparing offers of areas for residential development, Urząd Miasta Wrocławia, Wrocław, 2012.

- Ziniewicz, M. A. (2012). Administracyjnoprawne aspekty opłat adiacenckich. Warszawa, LexisNexis. 